\title{
An innovative approach to students'professional training in the context of heuristic learning
}

\author{
O. Kryvonos, M. Bykova, Zh. Chernyakova \\ Sumy State Pedagogical University named after A. S. Makarenko, Sumy, Ukraine \\ *Corresponding authors. E-mail: olyacrivonos058@gmail.com, m.bykoffa@gmail.com, janechernyakova@gmail.com
}

Paper received 02.05.20; Accepted for publication 18.05.20.

\section{https://doi.org/10.31174/SEND-PP2020-229VIII93-05}

\begin{abstract}
The article deals with the didactic opportunities of heuristic education as an innovative condition for the students' professional training. The role of various types of heuristic activity in the formation of such an important quality of future teachers as tolerance as well as students' professional and creative skills in the process of their participation in the student theatre is analyzed. The results of a pedagogical experiment on the formation of students' tolerance and their professional and creative skills are presented in the article.
\end{abstract}

Keyword: students' training, heuristic activity, a student theatre, tolerance, professional and creative skills.

Introduction. In the context of reforming the general secondary and higher education of Ukraine, its entry into the European educational space, a contradiction arises between the need to prepare a modern competent specialist and the capabilities of a higher educational institution to create an innovative educational environment, to ensure the implementation of the education goal specified in the Law of Ukraine «On Education» - the comprehensive development of a man as a person and the highest value of society, its talents, intellectual, creative and physical abilities, the formation of values and the necessary competencies for successful self-realization [3].

In the context of our research we have studied heuristic learning as one of the innovative conditions, which to a certain extent allows to achieve the indicated goal of Ukrainian higher education.

Analysis of relevant research. The primary sources of heuristic pedagogy, which is based on the priorities of the creative activity of those who study and those who teach, the researchers find in the philosophical and pedagogical practice of the ancient Greek philosopher Socrates (469399 BC). It was Socrates who called heuristics a new way of thinking and obtaining the truth [5, p. 215].

The scholars V. Andreev, V. Voronin, P. Kapterev, N. Lazarev, A. Khutorskoy have made a significant contribution to the scientific justification of the innovative possibilities of heuristic learning. The researchers argue that the hallmark of innovative heuristic educational activities is the student's design of his/her own education through the creation of products, included in the content of education. The external educational product of a participant of the educational process provides him/her with an internal product - change of knowledge, experience, abilities, skills, competences and other personal qualities. The internal product of a participant of the educational process is that a qualitatively new result that heuristic activity achieves.

$\mathrm{N}$. Lazarev points out that heuristic learning is not based on mandatory tasks, which mainly come from a teacher with external stimulation of activity, and on their own variable goal setting, defining the objectives and creating in this regard their own educational product. This training envisages sufficient knowledge of the mechanisms, methods and techniques of creative activity, such as «analysis through synthesis», brainstorming, a logical series of heuristic questions, methods for developing empirical knowledge to a theoretical level, associations, comparison, generalization, abstraction, objective diagnosis and evaluation of one's own or another's work [5, p. 222].

In our study we have included the following items to the innovative possibilities of heuristic learning:

1) an increase of the volume of independent creative activity in the educational process;

2) a thorough reliance on students' heuristic thinking and their heuristic experience when learning new things, the formation of professional abilities and skills;

3) assessment of knowledge, professional and creative skills of the students on the quality of the designed educational creative product;

4) the introduction of a criteria-diagnostic and level system for determining adequate, objective parameters of various types of professionally creative products during their creation, diagnosis and evaluation;

5) the provision of great importance to reflective activity;

6) motivation of cognitive activity of the students using various factors, in particular the transformation of the teacher's own creative experience;

7) widespread use of a complex of methods and mechanisms of creative activity, in particular heuristics;

8) resolution of the contradiction between the freedom of a student's cognitive and creative activity and the need for strict standards of their educational achievements [4, p. 118-119].

The aim of the article is the analysis of theoretical and experimental research of didactic possibilities of heuristic training in the formation of tolerance as well as professionally significant qualities of the students, definition of the tasks and directions of students' tolerance formation in the conditions of heuristic learning.

Materials and methods. The theoretical justification of heuristic learning has been carried out by us on the basis of analysis and synthesis, generalization of scientific literature on the research problem. The experimental study of the innovative possibilities of heuristic learning has been carried out both in the process of training of future teachers and future medical workers.

Results and their discussion. An important result of students' professional training in the conditions of heuristic learning is the formation of tolerance and multiculturalism, which significantly affect the development of the 
social climate, interpersonal relationships, the state of development of modern man and his education [1].

The Declaration of Tolerance Rights gives the following definition of the essence of the term: «Tolerance means respect, perception and understanding of the rich diversity of cultures of our world, forms of selfexpression and self-affirmation of a human person. The formation of tolerance is facilitated by knowledge, openness, communication and freedom of thought, conscience and belief. Tolerance is unity in diversity. This is not only a moral duty, but also a political and legal need. Tolerance is what makes peace possible, contributes to the transition from a culture of war to a culture of peace» [2]. Tolerance is, first of all, upbringing, which requires selfrestraint and allows you to relate to another from a position of equality [7].

The educators play an important role in the formation of students' tolerance. We define tolerance in the pedagogical sense as communication between an educator and students, built on the creation of optimal conditions conducive to the formation of a culture of communication among students, respect for the personality of the individual, the ability to freely express their own opinions. That is, the main feature of a tolerant educator is that he does not perceive the difference as a disadvantage.

Heuristic learning provides maximum potential for the formation of students' tolerance, as it declares and implements to a greater extent the process of interaction rather than influence. Such an environment forms a student's readiness for humane, tolerant behavior. The task of the educator is to teach students to behave and communicate tolerantly. Our classes have been based on a humanistic position, subject-subject approach, which involves: freedom of expressions and personality behavior in various forms of the pedagogical process; statement of mutual assessments and judgments of the educator and student on various occasions; the acquisition of an individual experience in the process of such an interaction; prevention of any violent or harsh measures regarding the restriction of the impulses and desires of the students.

The main directions of our work on the formation of students' tolerance in the conditions of heuristic learning are the following: the formation of student's perceptions of himself as a unique, self-sufficient personality; development of ideas about other people based on the definition of similar and distinctive features; students' awareness of their own abilities and their development; awareness of their strengths and weaknesses, identification of criticality; awareness of the rights and obligations in relation to oneself and other people; the formation of the ability to assert their rights and take into account the rights of others; determination of the rules and norms of human communication together with the students; the ability to evaluate their own actions and the actions of others; the ability to make choices, make decisions; to listen to the opinions of others and to resolve conflicts that arise; deepening understanding of the importance and value of every human life.

We have applied a set of methods and techniques of heuristic learning for the formation of students' tolerance. Among the main elements we have distinguished the following:

1) holidays and activities exploring the culture and tra- ditions of both the Ukrainian people and other nationalities. The aim is to study the folklore in order to obtain knowledge about the diversity of people;

2) the role-playing games are used to master the techniques of tolerant communication;

3) heuristic conversations (indicative topics for discussion: «About friendship», «About kindness», «Evil away», «Rules of behavior at the university», «What is mercy?»);

4) ethical conversations (proposed topics: «What you have done, how you have done», "What rights are, what responsibilities are»). Discussion of situations of humanistic choice;

5) brainstorming on the problem of determining the main features of a tolerant personality (for example, such features of a person as: respect for the opinions of others, goodwill, always focus on interaction, the ability to understand and accept the others, curiosity and responsiveness, condescension). For each indication it is necessary to create a pedagogical situation, to solve it together and thus consolidate not only theoretical knowledge, but also practical behavior skills;

6) business games are used to overcome the spirit of intolerance (intolerance).

The participants of the experiment have noted that participation in heuristic activities aimed at promoting tolerance allowed them to feel more confident in interpersonal communication, to reduce the level of intolerance to the interlocutors.

As a result of an experimental study, the level of students' tolerance has been determined by testing. It turned out that after we implemented various methods of heuristic activity, aimed at the formation of the investigated quality, 95\% of the students had an average level of tolerance.

The innovative possibilities of heuristic learning in the formation of professional and creative skills of future specialists have been experimentally tested in the training of medical workers as well. In particular, such a type of heuristic activity as the students' participation in the work of the student theatre was used. It was the anatomical theatre, which was attended by the students according to their wish (experimental group).

The purpose of this study was to identify the didactic opportunities of students' heuristic activity, including the form of the student theatre, in the formation of professional and creative skills of future specialists.

The analysis of the scientific literature has made it possible to determine that the theatre is one of the optimal conditions for actualizing the creative potential of a future specialist in a higher educational institution, [6, p. 177].

We refer students' creative activity in the anatomical theatre to heuristic activity, considering that the students on their own initiative created external educational products in the form of scenarios that included anatomical poems, dances on anatomical and physiological topics, songs dedicated to the functions and structure of the human body, prose on the same topic; besides, they acted as directors, costumers and actors. They were given the maximum freedom of intellectual activity, they independently created problem situations, looked for the ways to solve them, taking responsibility for the chosen solution. So, in the play «The Trial of Alcoholism», the stu- 
dents-actors played the following characters: judge Pravdivtsev, prosecutor Tverezovskaya, lawyer Nalyvaiko, secretary Pysarchuk, defendant Alcohol, the victims - the liver, pancreas, brain, heart, kidneys, witnesses - doctor Vseznaikin, nurse Sobolezkina, laboratory assistant Chitalkin. The authors of the script in half-hint form, but in compliance with the court procedure, the scientific nature of the information, demonstrated those changes which occurred in the structure and function of the organs in the abuse of alcoholic beverages. Thanks to participation in the anatomical theatre, the students developed such creative abilities as the originality of the vision of the anatomical and physiological pictures of the body, literaryfigurative embodiment of scientific information, presentation in an unexpected perspective of known functions with the help of «animation» and others.

In addition, the formed ability of the students to their own transformation and integration of special theoretical knowledge, their realization in the implementation of a creative project has become extremely important.

As an example, we can call the plays: «The body without the consent will be confusion» about the importance of the body's nervous system activity, «To each his own» about the activity and interdependence of the digestive system, «My blood» about the functions of blood and blood-forming organs and many others.

The participants of the anatomical theatre have noted that participation in the performance gave them the opportunity with the help of a poetic, literary form, to clearly, fully memorize and rethink scientific information, to create a picture that can be seen objectively at the level of imaginative vision. With such students' creative activities, a creative imagination, the first and second signaling systems developed, artistic abilities to possess voice, intonational expressiveness, fantasy, body plastic, facial expressions were formed, creative skills to express their emotional-figurative feelings in front of the viewer, to create a positive emotional mood, an inventive atmosphere, to control and manage their own emotionalvolitional state were molded.

We do believe that such students' heuristic activity in the educational process ensures the formation of their communicative, research, reflective creative skills that are important for a future specialist. In order to verify the effectiveness of experimental activity, we have compared the learning outcomes (average score) of the students who participated in the anatomical theatre and those who did not participate, but were just spectators (control group). It has been found that $72 \%$ of the participants in the anatomical theatre had a higher average score than the students in the control group.

The conclusions. Thus, it can be argued that the studies of the didactic capabilities of heuristic learning in the formation of tolerance as well as professionally significant qualities of the students have confirmed its effectiveness. It has been proved that the leading role in the process of formation of students' tolerance belongs to various methods of heuristic activity such as: heuristic and ethical conversations; role-playing games to master the techniques of tolerant communication; brainstorming on the problem of determining the main signs of a tolerant personality and others. These methods have ensured the mastery of the key competence that determines intellectual and personal development - it is the readiness and ability of a person to live and interact constructively in a multicultural world, which is one of the important professional qualities of an educator.

It has been also experimentally proved that the students' heuristic activity in the form of a student theatre is not only a spectacle causing aesthetic pleasure, but provides the formation of their communicative, research, reflective creative skills, which are of great importance in the professional activity of a future specialist.

\section{ЛИТЕРАТУРА}

1. Бикова М.М. Сучасні підходи до реалізації принципу полікультурності у вихованні// Педагогічні науки: теорія, історія, інноваційні технології : наук. журнал, 2018. 5 (79), С. 294-304.

2. Декларація принципів толерантності, 1995. Retrieved from: https://zakon.rada.gov.ua/laws/main/995_503

3. Закон України «Про освіту» [Електронний ресурс]. Режим доступу: https://zakon.rada.gov.ua/laws/show/2145-19.

4. Кривонос О.Б. Пізнавально-творча самореалізація майбутнього вчителя в евристичній освіті // Пізнавально-творча і професійна самореалізація особистості в евристичній освіті: тези всеукраїнської науково-практичної конфере-

нції (Суми, 22 - 23 лютого 2018 р.), С. 117 - 119.

5. Лазарєв М.О. Педагогічна творчість: навчальний посібник для студентів, магістрів, аспірантів педагогічного університету: 2-ге видання, доповнене і перероблене. Суми: ФОП Цьома С.П., 2016, 294 с.

6. Лимаренко Л. Використання студентського театру в європейських системах професійної підготовки майбутніх педагогів // Естетика і етика педагогічної дії, 2015. № 9, С. $176-187$.

7. Мириманова М. Толерантность как проблема воспитания// Развитие личности, 2002. 2, С. 14-115.

\section{REFERENCES}

1. Bykova, M.M. Modern Approaches to the Implementation of the Principle of Multiculturalism in Education // Pedagogical Sciences: Theory, History, Innovative Technologies: Scientific Journal, 2018. 5 (79), P. 294-304.

2. Declaration of Principles of Tolerance, 1995. Retrieved from: https://zakon.rada.gov.ua/laws/main/995_503

3. Law of Ukraine «On Education» [Electronic resource]. Access mode: https://zakon.rada.gov.ua/laws/show/2145-19.

4. Kryvonos, O.B. Cognitive-creative self-realization of the future teacher in heuristic education // Cognitive-creative and professional self-realization of a personality in heuristic edu-

cation: abstracts of the All-Ukrainian scientific-practical conference (Sumy, February 22-23, 2018), P. 117 - 119.

5. Lazarev, M.O. Pedagogical creativity: a textbook for students, masters, graduate students of the Pedagogical University: 2nd edition, supplemented and revised. Sumy: Tsyoma SP, 2016, $294 \mathrm{p}$.

6. Lymarenko, L. The use of student theatre in European systems of professional training of future teachers // Aesthetics and Ethics of Pedagogical Action, 2015. № 9, P. 176 - 187.

7. Mirimanova, M. Tolerance as a Problem of Upbringing // Development of Personality, 2002. 2, P. 14-115. 